\title{
Surgical Management of Fibrosarcoma of Teat in a Cow - A Case Report
}

\author{
C. Premsairam*, N. Aruljothi, T.P. Balagopalan, R. Kumar and R.M.D. Alphonse \\ Department of Veterinary Surgery and Radiology, Rajiv Gandhi Institute of Veterinary \\ Education and Research, Pondicherry - 605009, India \\ *Corresponding author
}

\section{A B S T R A C T}

\begin{tabular}{|l|}
\hline K e y w or d s \\
$\begin{array}{l}\text { Cow, Teat, Ulcerated } \\
\text { growth, ultrasonography } \\
\text { and Fibrosarcoma }\end{array}$ \\
\hline Article Info \\
\hline $\begin{array}{l}\text { Accepted: } \\
\text { 02 May } 2018 \\
\text { Available Online: } \\
\text { 10 June 2018 }\end{array}$ \\
\hline
\end{tabular}

\section{Introduction}

Fibrosarcoma is an uncommon tumor in bovines (Pandey et al., 1984). Most of these are tumors of soft tissue structures, including the mammary gland, retroperitoneal tissue, testicles viz., spermatic cord remnants following castration, neck, intestines, and reticulum.

There have also been several reports of congenital fibrosarcoma in calves (Britt et al., 1998). Mammary fibroadenoma and fibrosarcoma were reported in 7 months heifer and aged cow respectively. Teat fibroma and fibrosarcoma are smooth firm nodules covered by intact skin that occur at the base of the teat. Intramammary tumors and hyperplastic lesions cause firm localization to diffuse areas of mammary gland that may or may not result in overall enlargement of affected gland. Mastitis and fistulations can occur secondary to malignant tumors. Fibroma and fibrosarcoma consists of proliferating fibroblasts with admixed collagen and variable mitotic activity.

Fibroma and fibrosarcoma of the teat are typically localized lesions whereas the fibrosarcoma of the mammary gland was invasive. Surgical excision of teat fibromas and fibrosarcomas is apparently curative.

\section{Materials and Methods}

A seven year old pleuriparous cross bred jersey weighing around $268 \mathrm{~kg}$ was presented to Department of Veterinary Surgery and 
Radiology, TVCC, RIVER with a history of an abnormal mass hanging on the right fore teat (Fig. 1) since 4 years which was progressively increasing in size. On clinical examination, the mass was found to be ulcerated showing dribbling of milk continuously (Fig. 2). The right teat was found to be having normal teat orifice which was confirmed by probing with a sterile teat siphon (Fig. 3). The milk from the affected teat was normal in color, consistency, $\mathrm{pH}$ and negative for mastitis by California mastitis test. The physiological and haematological parameters were within the normal range.

Ultrasonographical images of the affected teat showed the teat diameter at the mid teat sinus as $23.3 \mathrm{~mm}$ with thickness of the teat wall as 9mm (Fig. 4). The condition was tentatively diagnosed as teat fistula connecting the teat sinus to the ulcerated growth and surgical correction was advised.

\section{Results and Discussion}

The animal was sedated by using Inj. Xylazine (Xylaxin- Indian Immunologicals, Hyderabad) @ $0.1 \mathrm{mg} / \mathrm{kg} \mathrm{I} / \mathrm{V}$ and local analgesia was achieved by ring block with Inj. $0.5 \%$ Bupivacaine hydrochloride.

The growth was excised from its attachments on the teat and the additional teat orifice other than the normal one was identified (Fig. 5), dissected and closed by simple continuous suture pattern using Polyglactin 910 of size 30 .

The muscular layer and skin were sutured separately using Polyglactin 910 (Vicryl Plus Johnson and Johnson, Mumbai) of size 3-0 in simple continuous pattern (Ghamsari et al., 1995 and Balagopalan and Aruljothi, 2016) and braided silk (Ethicon, Johnson and Johnson, Mumbai) of size 0 in simple interrupted pattern respectively. The teat patency was maintained with modified polyvinyl chloride tubeno.10 (Infant feeding tube, Romsons Scientific and Surgicals India) placed in situ and stay sutures applied. This was connected to a $2 \mathrm{ml}$ sterile disposable syringe and the sutured site was protected with elastic adhesive bandage (Dynafix) (Fig. 6).

Postoperatively Inj. Streptopenicillin (Dicrysticin- S- Zydus AHL) @ 10mg/kg for 7 days along with Inj. Meloxicam (Melonex ${ }^{\circledR}$, Intas Pharmaceuticals Ltd, Matoda, Ahmedabad) @0.3mg/kg for 5 days were administered intramuscularly.

The skin sutures were removed on $10^{\text {th }}$ postoperative day (Fig. 7) and ultrasound examination revealed hyperechogenicity of skin with normal echotexture, hypoechoiec teat wall with the presence of blood vessels confirmed the healing and intact anechoic teat sinus indicated the closure of teat fistula.

The teat wall thickness $(4.9 \mathrm{~mm})$ and teat sinus diameter $(7.9 \mathrm{~mm})$ were also measured (Fig. 8). Histopathological examination confirmed the condition as Fibrosarcoma (Fig. 9).

Tumors of mammary gland are uncommon in cattle. Fibroma and Fibrosarcoma of the teat occurs in yearlings. Reports on bovine fibrosarcoma compared with other tumors of cattle are very rare (Yeruham et al., 1999; Musal et al., 2007 and Birgit et al., 2004).

Modified PVC tubes employed was useful in maintaining patency of the teat lumen postoperatively which is in accordance with that observed by Aruljothi et al., (2012). Ultrasonography with water bath method using normal saline and $7.5 \mathrm{MHz}$ linear probe was found to be very useful tool in visualizing the fistulous tract which was connected to the tumorous growth preoperatively and to study the healing postoperatively (Franz et al., 2009 and Mulon, 2016). 


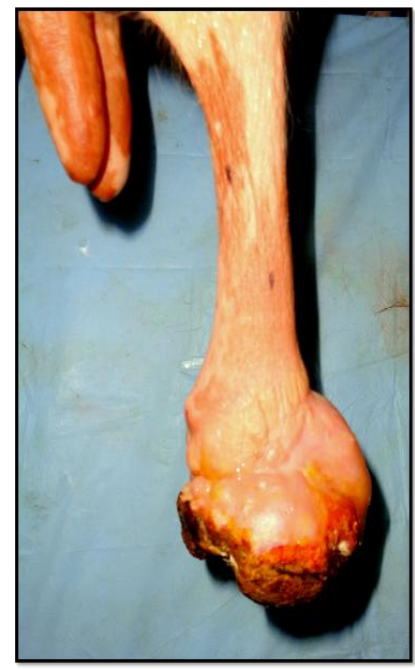

Fig.1Abnormal mass hanging on the right fore teat

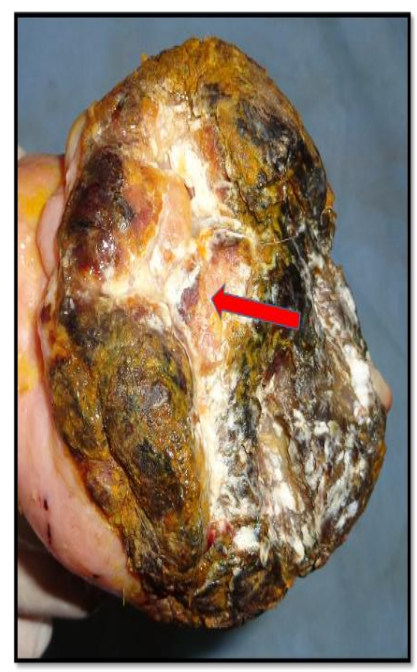

Fig.2 Ulceratedmass with dribbling of milk

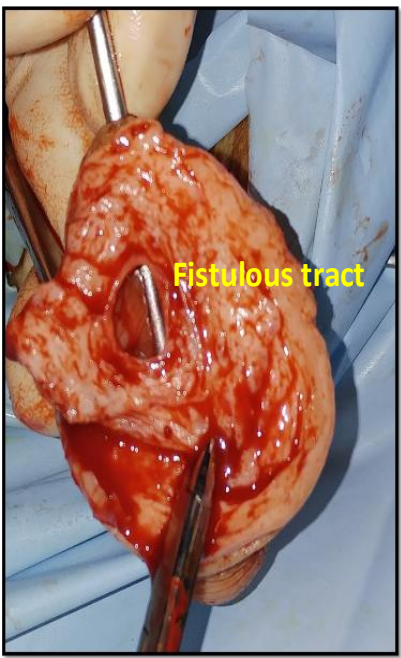

Fig.5After excision of the growth additional teat orifice other than the normal one was identified

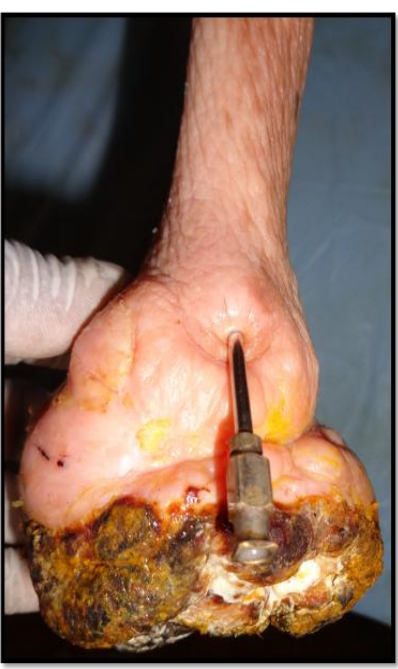

Fig.3Probing the teat sinus with a sterile teat siphon

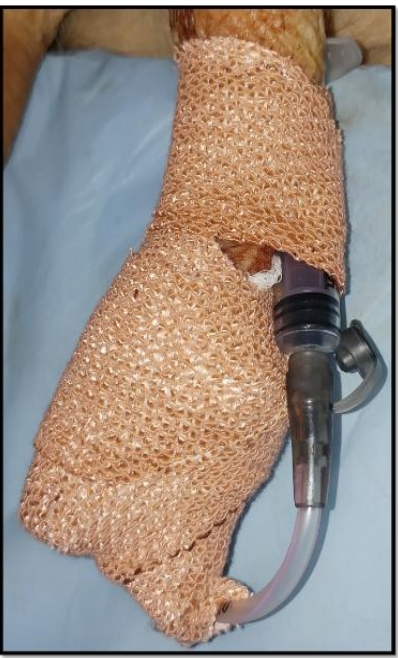

Fig.6Insitu placement of modified PVC tube which was connected to a $2 \mathrm{ml}$ disposable syringe and application of Dynafix, 


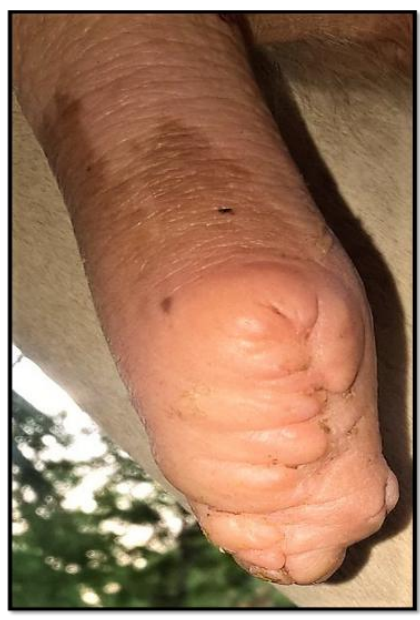

Fig.7Skin sutures removed on $10^{\text {th }}$ postoperative day

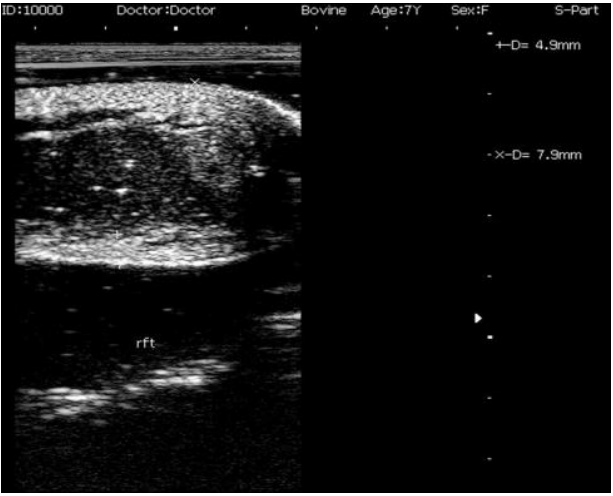

Fig.8 Ultrasound image on $10^{\text {th }}$ postoperative day showing hyperechogenicity of skin with normal echotexture, teat wall with blood vessel and anechoiec teat sinus

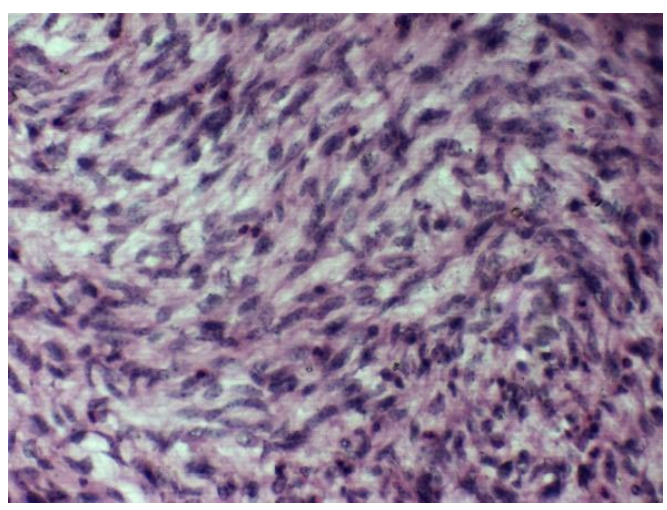

Fig.9Histopathological examination of the tissue showing the presence of inflammatory cells under $40 \mathrm{X}$

As the ultrasonography is an effective tool to diagnose the pathological alterations such as congenital changes, inflammation, mucosal lesions, tissue proliferation, foreign bodies, milk stones, haematoma and abscess (Szencziová, and Strapák 2012).

The present case discussed the occurrence of fibrosarcoma with the presence of fistula of teat in a seven year old cross bred jersey and its successful surgical management.

\section{Acknowledgement}

The authors are thankful to the Dean, Rajiv Gandhi Institute of Veterinary Education and Research, Pondicherry for the facilities provided to conduct the study.

\section{References}

Aruljothi, N., Balagopalan, T.P., Rameshkumar, B., and Alphonse, 
R.M.D. (2012). Teat fistula and its surgical management in bovines. Intas Polivet. 13(1): 40-41

Balagopalan, T.P and Aruljothi, N. 2016. Surgical management of webbed teat in a cow. JAVS, 9 (7): 84-86.

Birgit, M. Kofler, J., Huber, J. and Schilcher, F. (2004). Neoplasms of the extremities in cattle-clinical findings, surgical treatment and outcome in 10 cases. Proceedings of the 13 International Symposium and 5 Conference on Lameness in Ruminants $11-15$ February 2004, Maribor, Slovenija, Pp: 4-6

Britt, L.G., Ms, Middleton, J.R., Valdez, R.A., Tucker, R.L., Parish, S.M. and Tyler, J.W. 1998. Facial Fibrosarcoma in two Cows. Veterinary Radiology \& Ultrasound, 39(1): 18-21.

Franz, S., Floek, M. and Hofmann-Parisot, M. 2009. Ultrasonography of the bovine udder and teat. Vet. Clin. North Am. Food Anim. Pract., 25: 669-685.
Ghamsari, S.M., Taguchi, K., Abe, N., Acorda, J.A., Sato, M. and Yamada, H. 1995. Effect of different suture patterns on wound healing of the teat in dairy cattle. J. Vet. Med. Sci., 57: 819-824.

Mulon, P.Y. 2016. Surgical management of the teat and the udder. Vet. Clin. Food Anim., 32: 813-832.

Musal, B., Ultas, P. and Aydogan, A. (2007) Vaginal fibrosarcoma in a cow. Irish Vet. J. 60: 424-425

Pandey, G.S., Sharma, R.N. and Chizyuka, H.G.B. 1984. Study of bovine neoplasms in Zambia. Bull Anim Hlth Prod Afr; 32: 289-291.

Szencziova, I., and Strapak, P. 2012. Ultrasonography of the udder and teat in cattle. A perspective measuring technique. Slovak. J. Anim. Sci., 45: 96104.

Yeruham, I., Perl, S., Orgad, U. and Yakobson, B. (1999). Tumors of the vulva and vagina in cattle - a 10-year survey. Vet. J. 158: 237-239.

\section{How to cite this article:}

Premsairam, C., N. Aruljothi, T.P. Balagopalan, R. Kumar and Alphonse, R.M.D. 2018. Surgical Management of Fibrosarcoma of Teat in a Cow - A Case Report. Int.J.Curr.Microbiol.App.Sci. 7(06): 282-286. doi: https://doi.org/10.20546/ijcmas.2018.706.033 